\title{
Innovative Ability Mission of the Enterprising University
}

\author{
Berta Ermila Madrigal Torres ${ }^{1}$, Marco Alberto Núñez Ramírez ${ }^{2}$, Rosalba Madrigal Torres ${ }^{3}$, Ricardo \\ Arechavala Vargas ${ }^{4}$ \\ ${ }^{1}$ Researcher (S.N.I) at Universidad de Guadalajara (CUSUR) madrigal@cusur.udg.mx and agenda.madrigal@gmail.com \\ ${ }^{2}$ Instituto Tecnológico de Sonora. marco.nunez@itson.edu.mx \\ ${ }^{3}$ Professor at Universidad de Guadalajara (CUCSH) rosalbam@csh.udg.mx \\ ${ }^{4}$ Researcher (S.N.I) at Universidad de Guadalajara (CUCEA). yukoneagle2@yahoo.com
}

How to cite this paper: Torres, B.E.M., Ramírez, M.A.N., Torres, R.M., Vargas, R.A. (2019) Innovative Ability Mission of the Enterprising University. International Journal of Humanities, Arts and Social Science, 3(2), 32-42

DOI: $10.26855 /$ jhass.2019.09.001

*Corresponding author: Berta Ermila Madrigal Torres, Researcher (S.N.I) at Universidad de Guadalajara (CUSUR) madrigal@cusur.udg.mx and agenda.madrigal@gmail.com

\begin{abstract}
Comparative research of the entrepreneurial University VS innovator and students who have studied a curriculum that promotes entrepreneurship and those who did not. Hypothesis 1 , the student who receives entrepreneurial training has more developed innovative and entrepreneurial skills. Hypothesis 2, there is no difference between one student and another. The population is made up of 522 students from various Universities in Mexico. In order to identify the profile of the entrepreneurial and innovative University, the Ranking 2018 was used as well as an Instrument Barometer INCODE (innovation competences development) to determine the $E z$ of the students, which is a learning program of the European Union. The results showed the importance of fostering the innovative ability of the student, curricular and extracurricular, since this is a cross-cutting skill that all professionals require to undertake any project or strategy with an emphasis on entrepreneurship and innovation demanded by the environment and the entrepreneurial University in all contexts. The study gives us the opportunity to develop the transversal skills in line with the mission of the University. Also, the challenge of transition from the University of teaching to the entrepreneurial and innovative University.
\end{abstract}

\section{Keywords}

Entrepreneurial University, Innovative University, innovative ability, entrepreneurial ability

\section{Introduction}

The study shows the importance of measuring the entrepreneurial and innovative ability of the student, which help to shape specific training programs in the classroom either curricular or extracurricular, according to Drucker (1985) and Schumpeter (1934) and classics of innovation, as well as the contemporary theories of the two skills and universities mentioned in the theoretical framework.

It presents the approach to the problem of entrepreneurial education and culture of the student in Latin America, specifically in Mexico, from the incipient programs for this, to consolidate a public and University policy for the government and Universities as well as to consolidate the training with these two transversal skills. In this regard, it is perceived how both the formal and informal factors of entrepreneurship are being consolidated as established by Madrigal and Santamaria (2013).

The approach of theories of the scope of entrepreneurship, innovation, challenges of the entrepreneurial and innovative University, from which we have more research questions to address the Universities of Latin America versus those that 
have been consolidated in other countries as enterprising Universities.

In the methodology section, it is widely described from the sample to the methodological instruments used. Hence, the research goes in line with measuring and comparing the skills developed by students from different Universities in Mexico. Along with these diagnoses and results, it is suggested in the conclusions section, that a strategic project should be used to develop the innovative, entrepreneurial skills and above all, the social capital required by the students and future professionals. Likewise, we analyzed the scope of the entrepreneurial and innovative University by Ranking, which focused on forming innovative and entrepreneurial students. The new research questions were designed to strengthen the innovative and entrepreneurial culture in educational environments.

\section{Problem Statement}

There is a belief that the development of entrepreneurship globally is largely due to its promotion in business schools and universities (Etzkowitz, 2013). This is based on the fact that higher education has become a strategic factor of economic and technological development, whose aim is to provide answers to the different social and economic problems (World Bank, 1995). Thus, the current University, which is becoming more and more evident around the world, in its attempt to compete with the world markets - such as innovation (Schumpeter, 1934), has begun its transition towards becoming an entrepreneurial University (Etzkowitz et al., 2008; Guerrero and Urbano, 2012).

However, very little on the entrepreneurial University in Mexico has been studied (Miranda, Molina and López, 2014; Nuñez et al., 2018), although, it stands out beyond trying to explain and shape the entrepreneurial university, the Mexican Higher Education Institutions (IES) have put in a lot for the development of business incubators (Arreola, 2014). This is an important advancement, but a greater effort is required in this region to meet the demands of the market and University graduates; as well as the connection and development with the informal aspects of entrepreneurship.

According to Fairlie and Woodruff (2007), Mexico is an entrepreneurial country, however, it has been over three decades anincipient strategic plan was initiated to generate entrepreneurs with the linkage of the Government and the Universities. Thus, the need to create national and international policies, both educational and governmental that are oriented towards the formation of a culture of innovation and entrepreneurship, and with these entrepreneurs, they are capable of generating employment in developing countries, such as Mexico (Madrigal and Contreras, 2008).

In spite of the above, in Mexico, there is a lack of theoretical and empirical framework to enable better understanding of the phenomenon of entrepreneurship and innovation within Mexican Universities. It is important to note that these can be important seedbeds of entrepreneurs, if a strategy is elaborated andoriented towards meeting this need. Thus, the following research questions arise: Are there significant differences in the development of entrepreneurial skills among University students who have received training in entrepreneurship? Are individual, interpersonal and networking skills significantly associated? Do individual competencies influence interpersonal skills and networking?

\section{Theoretical Framework}

In this case, three variables are addressed: entrepreneurial ability, innovative ability and an entrepreneurial and innovative University. Entrepreneurship is a transverse skill that is also educable. Therefore, for the purpose of this study, the scope of the World Economic Forum (2014) is assumed to be highly impactful and it is highly beneficial to consumers with the use of innovations, which likewise these enterprises generate job opportunities and greater wealth for the owners. On the other hand, Contreras and González, (2010) defined entrepreneurship; as the search for a constant change, generation of ideas, the speculation of projects that is beneficial to the economy and society, as those initiatives of an entrepreneurial nature show the way to being an individual where the way of thinking, reasoning and acting are included, with the search for a business opportunity, which result in initiatives that generate value, not only in an economic sense, but it is also concerned with the social aspects, where all actors involved in the initiative, ranging from owners, employees, customers, suppliers and the society in general enjoy this benefit.

Baumol (1990) refers to productive entrepreneurship as the fundamental pillar in innovation, which generates economic growth and can be associated with the discovery of good business opportunities, processes, ideas and strategies. For everyone in their category, they reach the same point whereby they describe the entrepreneur as the one who manages to find opportunities that generate greater benefits and they use innovations that sustain and exploit the opportunity. 
This type of entrepreneurs who focus on their clients are the ones that generate more wealth for their owners (Hitt, Ireland, Sirmon and Trahms, 2011). These entrepreneurs tend to plan their actions better from the moment they enter the market in an anticipated manner and the most usual is that they take up markets in which they have already had interaction, this reduces their failure rate compared to situations whereby there is no such planning and knowledge of the market (Liñán, Fernández-Serrano, Romero, 2013).

The relationship between entrepreneurship and innovation and the impacts of these has been widely studied by multiple authors. An obligatory reference of this is Joseph Schumpeter, who in his book, Theory of Economic Development (1912) and (1943), refers to the innovative entrepreneur as that person who is capable of creating something new or improved from the resources available to him.

Currently, both entrepreneurship and innovation are two skills to develop and its issues have been taken up by Universities and governments of different countries as a driver for the generation of economic development. At the University level, entrepreneurship and innovation are transversal knowledge, whereas in the case of Universities in Mexico, since the nineties, there are indications on how they are implemented in the curricula and at the beginning of year 2000, they begin with extracurricular activities, as well as the incubators and entrepreneurship centers.

\subsection{Innovation}

There is enough literature on the concept and scope of innovation as well as how it relates to technology and the company, processes among others. In this case, we will address those related to the variable of entrepreneurship with the case of Schumpeter (2003), Drucher, (1985) and Tonaka Glaudeand Gault 2005 and contemporaries such as Barber, Donnelly and Rizvi (2012), and Aznar, Montero, Pérez, Watts, Garcíaand Marin (2015), Kairisto (2013), Padilla Muñoz (2016) among others. Also, official bodies such as the OECD (2006, p.56), defined innovation as "the introduction of a new, or improved product (good or service), of a process, of a new marketing method or of a new organizational method, in the internal practices of the company, the organization of the workplace or external relations". This requires that both the student and the entrepreneur have and develop their entrepreneurial skills.

The skills for innovation are based on the FINCODA Project (Framework for Innovation Competencies Development and Assessment) as well as on three types of individual and interpersonal skills and the ability to create networks. The first is the ease, competence, talent, and / or expertise that a person or student has in this case; while interpersonal ability is the ability to interact with others and these range from their creative capacity, innovation, leadership among others. Therefore, we look forward to the results of our study taking the two variables into consideration.

Therefore, you must discover in the student his Entrepreneurial Spirit to bring him closer to knowledge through research, developing his entrepreneurship and innovative ability which makes him standout in his environment. In this sense, Barber, Donnelly and Rizvi (2012) mentioned that, if you start working hard in school to develop innovation skills, by year 2032, you would have an innovative community in development, but what happens in Mexico? What is the agenda around this need and what model does it have?

\subsection{The Entrepreneurial and Innovative University}

According to Schulte (2004), this includes two basic tasks: 1) Train future entrepreneurs, who will be creators of new businesses, as well as 2) develop the entrepreneur spirit across its educational areas, through the development of certain competencies in students both individual, interpersonal and networking; and two other variables such as: knowledge generation and knowledge marketing, as well as start-up and spin-off generation. In this regardand going by the definition of Corti and Riviezzo (2014), the entrepreneurial University is the one capable of generating knowledge and marketing it.

According to the Top Ten or Ranking of the enterprising Universities in 2018, the characteristics of the same one are identified ("Reuters Top 100", 2018).

1. Mission and vision of the University towards entrepreneurship inside and outside the classroom

2. Percentage of professors, students, alumni who successfully participate in business activities

3. Tutorials on entrepreneurship

4. Scholarships and financing for business studies 
5. Supports for the competitions of business plans sponsored by the school

6. Curricular and extracurricular programs of entrepreneurship

7. Companies created by their graduates in 10 years and levels of collection.

They are similar to an entrepreneurial University

If we analyze the profile of the innovative university, they are related to the entrepreneurial university and these are:

1. Intellectual property that they generate and this is measured in relation to the number of patents registered with the world Intellectual Property organization in five years. (Thomson Reuters)

2. Innovative and original research.

3. Create and develop useful technology.

4. They stimulate the global economy.

5. No. of researchers and their talent

Therefore, we see the value chain of the innovative university. Is it related to the value chain of the entrepreneurial University?

Diagram No. 1 value of an innovative university.

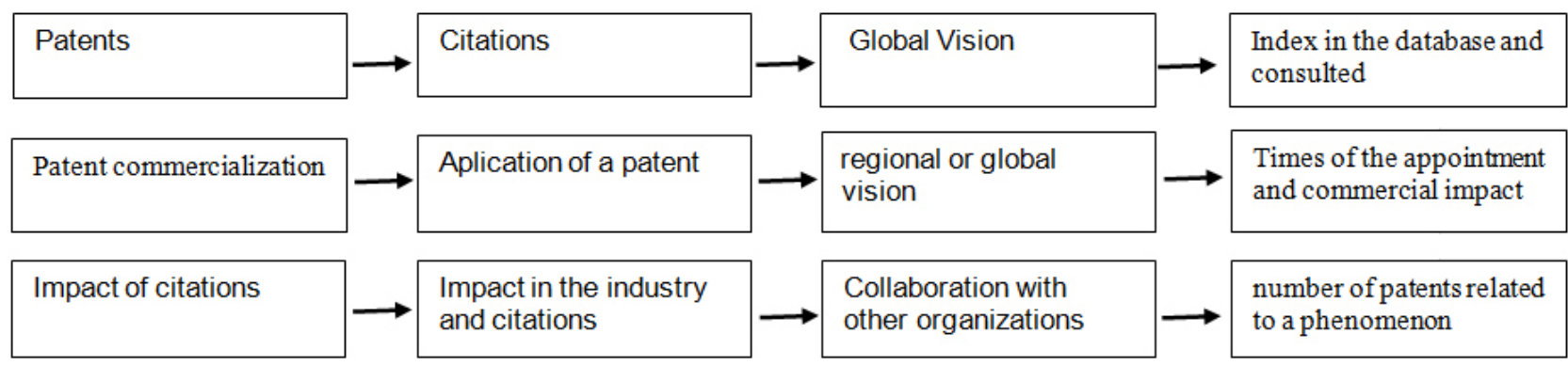

Sources: Own Elaboration, 2019.

As shown in the diagram, the entrepreneurial university and the innovative university have similar characteristics and profiles, since the two skills are required to undertake and innovate in the context of business. Based on this, we seek answers: Where is the Latin American University? What is missing to reach these indicators and be able to compete with innovative universities? Is it necessary to be an entrepreneur or innovator? Is innovation necessary prior to undertaking something new or innovative? Because we can undertake projects that do not have the impact, or solve problems with the same capacity for innovation.

This reason led to the need to develop a strategic innovation plan, starting from the general to the particular. First, the organizational structure which strengthen the formal and informal factors of entrepreneurship and innovation policy linked to a knowledge management program that becomes an enterprising and innovative university.

If we conduct the comparative analysis with the Ranking of the entrepreneurial Universities, we will find the first five that coincide with being innovative, this indicates that we must strengthen these skills in the student and that, like the Ranking, despite being global and integrative, they do not measure only one area of knowledge but the whole University. This indicates the great challenge faced by Latin American Universities (UL) in transiting from a University based on teaching to becoming an entrepreneurial University. Is it required? A structure, a philosophy, to reorient its mission and vision or only to form entrepreneurs? What can UL learn from entrepreneurial and innovative Universities? ("50 Best U.S. Colleges for Aspiring Entrepreneurs", 2014).

Therefore, our research begins from having and knowing the capacity, talent and skills of the teaching staff, students and actors of the regional context, similar with the FINCODA program and Spain. In this case, an advancementin the student research project at the undergraduate level is presented. 


\section{Research Design of the Student's Innovative Skill}

The research is a quantitative type of descriptive-comparative and correlational scope; this was because we sought to specify the properties, characteristics and profiles of a phenomenon describing its trends (Creswell, 2014), as well as measuring the association between the study variables (Hernández, Fernández-Collado and Baptista, 2010). A nonexperimental research design was used, because no type of manipulation was done in the selection of the subjects or in the variables (Gómez Bastar, 2012).

\subsection{Participants}

The study consist of a non-probabilistic sample for convenience made up of students from different Universities in Mexico, where "the University of Guadalajara", "the National Technological System", "The Universidad Veracruzana", "the Universidad Juárez Autónoma de Tabasco", "the Universidad Iberoamericana" and others stand out. Table 1 shows the characteristics of the sample studied.

Table 1. Characterization of the sample $(N=522)$

\begin{tabular}{lll}
\hline Characteristic & $\boldsymbol{n}$ & $\mathbf{\%}$ \\
\hline Gender & 199 & 38.1 \\
Man & 323 & 61.9 \\
Woman & & \\
Work Currently & 157 & 30.1 \\
$\quad$ No & 113 & 21.6 \\
Yes & & \\
University of origin & 211 & 40.4 \\
Universidad de Guadalajara (UdeG) & 11 & 2.1 \\
Universidad Juárez Autónoma de Tabasco & 44 & 8.4 \\
Universidad Veracruzana & 70 & 13.4 \\
UdeG CUSUR & 27 & 5.2 \\
Sistema Tecnológico Nacional & 159 & 30.5 \\
Others & & \\
Work Experience & 248 & 47.5 \\
Yes & 232 & 44.4 \\
No & 42 & 8.0 \\
Not Specified & &
\end{tabular}

Sources: Own Elaboration 2017

\subsection{Instrument for Measurement}

For data collection, the INCODE Barometer for Innovation was used, developed in the INCODE Project of the LifeLong Learning Program of the European Union (Watts, García and Andreu, 2013), which consists of twenty five items. A 10 points Likert scale was used, where one represents very little and ten represents excellent. It should be noted that this instrument is designed in three dimensions: 1) individual competencies (twelve items); 2) interpersonal competencies (eight items); and 3) competencies for networking (five items). (See Annex 1).

Students of different Universities applied the instrument through the Network of Collaborating Researchers of the project and summer students of Scientific Research 2016. The method of data capture consisted in the filling of the online barometer, with previous instructions for its filling. The capture period was from January 2016 to March 2018. 


\section{Results}

In order to test the first hypothesis of study -in the first moment- the student's T analysis was used, where it was possible to observe that there are no significant differences when considering students who have work experience and those who do not (See table 2).

Table 2. Comparison of means according to students who have work experience $(N=522)$

\begin{tabular}{|c|c|c|c|c|c|c|c|}
\hline & \multicolumn{2}{|c|}{ YES } & \multicolumn{2}{|c|}{ NO } & \multirow{2}{*}{ ET } & \multirow{2}{*}{$t$} & \multirow{2}{*}{$p$} \\
\hline & $M$ & $S D$ & $M$ & $S D$ & & & \\
\hline Individual & 7.18 & 2.09 & 6.95 & 2.12 & .132 & 1.215 & .225 \\
\hline Interpersonal & 7.71 & 1.89 & 7.42 & 1.97 & .120 & 1.642 & .101 \\
\hline Creation & 7.76 & 1.98 & 7.52 & 2.05 & .126 & 1.256 & .210 \\
\hline
\end{tabular}

Note. Own Elaboration, 2017.

On the other hand, in order to give continuity to the test of this hypothesis, ANOVA (analysis of variance) of a factor was used, through which it was found that there are statistically significant differences when considering the group as a comparison element to which these students belong. It is important to note that this happens in the three competencies measured by the instrument, see table 3 .

Table 3. one-way ANOVA $(N=522)$

\begin{tabular}{|c|c|c|c|c|c|c|}
\hline & & Sum of Squares & df & Mean Quadratic & $F$ & Sig. \\
\hline \multirow[t]{3}{*}{ Individual } & Between-groups & 206.022 & 9 & 22.891 & 5.876 & .000 \\
\hline & Within-groups & 1975.220 & 507 & 3.896 & & \\
\hline & Total & 2181.242 & 516 & & & \\
\hline \multirow[t]{3}{*}{ Interpersonal } & Between-groups & 143.002 & 9 & 15.889 & 4.635 & .000 \\
\hline & Within-groups & 1738.106 & 507 & 3.428 & & \\
\hline & Total & 1881.108 & 516 & & & \\
\hline \multirow[t]{3}{*}{ Creation } & Between-groups & 184.549 & 9 & 20.505 & 5.525 & .000 \\
\hline & Within-groups & 1874.361 & 505 & 3.712 & & \\
\hline & Total & 2058.910 & 514 & & & \\
\hline
\end{tabular}

Sources: Own Elaboration, 2017.

The empirical evidence obtained corroborates H1, where it is possible to observe that the training received by students in the Universities studied does have a positive impact on the development of both individual and interpersonal skills and the creation of networks. These findings are in agreement with that of Etzkowitz (2013), Gibb, Haskins and Robertson (2009), and Robinson and Haynes (1991), who argued that the development of entrepreneurship around the world is largely due to its promotion in schools of business and Universities.

Regarding reliability, that is, the internal consistency of the instrument (Hernández, Fernández-Collado and Baptista, 2014), alpha values of 0.965 were obtained for individual competencies, 0.952 for interpersonal skills and 0.935 for networking. Such results are favorable and reliable (see table 4).

Furthermore, for such competencies to be developed as a whole within University education, there is need to generate strategies that promote their integral promotion. This shows the importance of relationship. For this reason, to test $\mathrm{H}^{3}$, which holds that there is a significant relationship between competencies, Pearson correlation was performed, through 
which significant and positive relationships were found between the individual-interpersonal competencies $(\mathrm{r}=.794$; $0.01)$, individual-networking $(r=.750 ; 0.01)$, as well as interpersonal and networking $(r=.817 ; 0.01)$ (See Table 4).

Table 4. Correlation of competences $(N=522)$

\begin{tabular}{lcccccc}
\hline & $\boldsymbol{M}$ & $\boldsymbol{S D}$ & Reliability & Individual & Interpersonal & Creation \\
\hline Individual & 7.09 & 2.05 & 0.965 & 1 & & \\
Interpersonal & 7.57 & 1.90 & 0.952 & $.794^{* *}$ & 1 & \\
Creation & 7.63 & 2.00 & 0.935 & $.750^{* *}$ & $.817^{* *}$ & 1 \\
\hline
\end{tabular}

** The correlation is significant at level 0.01

Sources: Own Elaboration, 2017.

However, the empirical evidence found went further, since it was found that individual competencies have a positive influence on interpersonal skills $(\mathrm{B}=.74 ; t=29,749, p=0.00)$ and on the creation of networks $(\mathrm{B}=.70 ; t=25.727, p=$ 0.00 ), with $\mathrm{R}^{2}$ explaining $63 \%$ and $56 \%$ of the variance respectively (See table 5 ).

Table 5. Linear regression having as an independent variable: "individual competences" $(N=522)$

\begin{tabular}{lccccc}
\hline Factor & $\mathbf{S E}$ & $\mathbf{B}$ & $\boldsymbol{t}$ & $\boldsymbol{p}$ & $\mathbf{R}^{2}$ \\
\hline Interpersonal & 0.03 & 0.74 & 29.749 & .00 & 0.63 \\
Creation & 0.0 & 0.70 & 25.727 & .00 & 0.56 \\
\hline
\end{tabular}

Sources: Own Elaboration, 2017.

\section{Conclusions}

The comparative analysis of the characteristics and profile of the entrepreneurial University according to the Ranking consulted identifies that both are linked to the generation of knowledge and with it its intellectual property that are reflected in patents, but related to research. In this case, the Latin American and Mexican Universities are in transition from being a University based on teaching to the enterprising University with an emphasis on research for which they will have to consider.

In relation to the innovative and entrepreneurial skills of the student, it was identified that by using inferential statistics -one-way ANOVA, Pearson correlation and linear regression- they showed that there are significant differences in the students who received some type of competency development, both individual, interpersonal and collaborative networking. This reflects the importance of fostering the entrepreneurial spirit among University students, within the Mexican context, but globally. Likewise, such results allow us to observe that these competencies, in addition to having a strong relationship, have as their central point individual skills, since these can be considered as the basis for the development of interpersonal skills and the creation of collaborative networks. Therefore, this study emphasizes that it is necessary, within the context of the emerging model of entrepreneurial university, to take the student as an individual, so that it is possible to develop entrepreneurial skills that involve aspects not only psychological, but also social, cultural, administrative and technical.

All educational policy and strategy, pedagogical education must be supported by studies and diagnoses such as this case, in order to know and identify the skills of innovation and entrepreneurship of the student. The analysis and measurement of the entrepreneurial and innovative ability of the student will lead us to form specific training programs in the classroom whether curricular or extracurricular, according to Drucker (1985), Schumpenter (1934), Watts, García Carbonell and Andreu-Andrés, (2013). This study is important to support either the potential entrepreneur or the student for their innovative orientation. On the other hand, it was found in the study that young people who are involved in extracurricular activities presented a higher value in innovation skills, therefore, the hypothesis is verified and with this, it is recommended to increase the number of laboratories in the training of young University students. This means that 
innovation generates ideas that can be sold in a specific market (Schumpeter, 2003).

Therefore, it is necessary to identify the innovative and entrepreneurial skills of University students in the 21 st century. But at the same time, the crucial role played by educational institutions should not be overlooked, as there is evidence that teaching schemes which focused on work outside the classroom allow the development of individual, interpersonal and networking skills,especially if you are in multidisciplinary groups (Putkone, 2013). Hence, the research goes in the sense of measuring and comparing the skills developed by team students from different Universities. Along with these diagnoses, a strategic project is designed to develop both innovative, entrepreneurial skills and above all, the social capital required by the environment.

The student who has more developed interpersonal skills is able to easily establish innovative skills and establish collaborative networks. Innovation increases the level of competitiveness, but it is necessary to develop managerial and leadership skills, both for managers, businessmen and students. The innovative ability increases the level of competitiveness, it is not exclusive in the productive process, it must be developed by the management and the top management so that it positively affects all areas of the company.

New research questions arising from our study include the following; what is the innovative ability of the student by sex, age, career profile, as well as the comparative analysis between students from different institutions. What is the difference? What should be done to raise the level of innovation of the student?Similarly,we analyzed macro versus micro studies or the innovative ability of the student to evaluate the relationship (Mackinlay and Sabbagh, 2012) and (Kelley and Littman, 2005) because innovation should be measured in its own development activities such as; patents, number of products launched, investment in projects, innovative instances, percentage of enterprises, that is, efficiency and productivity actions related to the entity or individual that generates the aforementioned conditions.

\section{References}

[1] Arreola, J. (24 de julio de 2014). Las universidades y su impacto en el emprendimiento en México. Forbes México. Retrieved from: https://www.forbes.com.mx/las-universidades-y-su-impacto-en-el-emprendimiento-enmexico/\#gs.\%20Ut4BMDk

[2] Aznar M., L. E., Montero F, B., Pérez P., M. J., Watts, F., García C., A., Marin G., J. A. (2015). De proyecto INCODE a FINCODA: Utilización del Barómetro INCODE en alumnos universitarios y empleados con competencias de innovación: En In-Red - Congreso de Innovación Educativa y Docencia en Red de la Universitat Politécnica de Valencia. Retrieved from: https://riunet.upv.es/handle/10251/98866

[3] Banco Mundial (Word Bank) (1995). La enseñanza superior. Las lecciones derivadas de la experiencia. Washington, DC: Autor.

[4] Barber M, Donnelly, K. and Rizvi, S. (2012) Oceans of Innovation: The Atlantic, the Pacific, Global Leadership and the Future of Education, London: IPPR. Retrieved from: http://www.ippr.org/publication/55/9543/oceans-ofinnovation-theatlantic-thepacific-global-leadership-and-the-future-of-education

[5] Baumol, W. (1990). Entrepreneurship: Productive, Unproductive, and Destructive. Journal of Political Economy, 98(5), 893-921. Available at: https://www.jstor.org/stable/2937617

[6] Contreras Comeche, R. \& González García, N. (2010). La Medición del Valor Social y el Impacto de los emprendedores sociales. In: J.R. Sanchis Palacio (Dir.), Emprendimiento, economía social y empleo, IUDESCOOP, Instituto Universitario De Economía Social Y Cooperativa Dela Universidad De Valencia, Valencia, 141-157.

[7] Corti, E. \& Riviezzo, A. (2014). Hacía la Universidad Emprendedora, un análisis del compromiso de las universidades italianas con el desarrollo económico social. Retrieved from: https://eco.mdp.edu.ar/cendocu/ repositorio/00880.pdf

[8] Creswell, J. W. (2014). Research design: qualitative, quantitative, and mixed methods approaches. (4th ed.). USA: SAGE. Publications. 
[9] Drucker, P. (1985). Innovation and entrepreneurship: Practice and principles. New York, USA: Harper \& Row.

[10] Duarte, T., \& Ruiz, M. (2009). Emprendimiento, una opción para el desarrollo [Entrepreneurship, an option for the development]. Scientia et Technica, 15(43), 326-331. Retrieved from: http://www.redalyc.org/articulo. $\underline{\text { oa? id }=84917310058}$

[11] Etzkowitz, H. (2013). Can a teaching university be an entrepreneurial university? Civic entrepreneurship and the formation of a cultural cluster in Ashland, Oregon. Working paper. Birkbeck College, University of London, UK. Retrieved from: http://eprints.bbk.ac.uk/8474/1/8474.pdf

[12] Etzkowitz, H., Ranga, M., Benner, M., Guaranys, L., Maculan, A. M., \& Kneller, R. (2008). Pathways to the entrepreneurial university: Towards a global convergence. Science and Public Policy, 25(9), 681-695. Retrieved from: http://spp.oxfordjournals.org/content/35/9/681.short

[13] Fairlie, R. W., \& Woodruff, C. (2007). Mexican entrepreneurship: A comparison of self-employment in Mexico and the United States. In G. J. Borjas (Ed.), Mexican immigration to the United States (pp. 123-158). University of Chicago Press. Retrieved from: http://www.nber.org/chapters/c0100.pdf

[14] Friar, J. H., \& Meyer, M. H. (2003). Entrepreneurship and start-ups in the Boston region: Factors differentiating high-growth ventures from micro-ventures. Small Business Economics, 21(2), 145-152. https://doi.org/10.1023/ A:1025045828202

[15] Fuentelsaz, L., González, C., \& Maícas, J.P. (2015). ¿Ayudan Las Instituciones a entender el Emprendimiento? Economia Industrial, 113-121. Retrieved from: https://www.mincotur.gob.es/Publicaciones/ Publicacionesperiodicas/EconomiaIndustrial/RevistaEconomiaIndustrial/400/FUENTELSAZ, \%20 GONZ\%C3\%81LEZ\%20y\%20MAICAS.pdf

[16] Gastón Guirao, F. (2013). Gestión del conocimiento y redes sociales corporativas. Available at: http://www. improva-consulting.com/improsofia-blog/2013/06/24/gestion-del-conocimiento-y-redes-sociales-corporativas

[17] Gómez Bastar, S. (2012). Metodología de la investigación. México: Red Tercer Milenio. Retrieved from: http:// www.aliat.org.mx/BibliotecasDigitales/Axiologicas/Metodologia_de_la investigacion.pdf

[18] Gibb, A., Haskins, G., \& Robertson, I. (2009). Leading the entrepreneurial university. Meeting the entrepreneurial development needs of higher education institutions. National Centre for Entrepreneurship in Education (NCEE), University of Oxford. Retrieved from: http://eureka.sbs.ox.ac.uk/4861/1/EULP__LEADERS_PAPER_final_ dec 19.pdf

[19] Gibb, A. (2013). The Entrepreneurial university concept-20 key questions. In P. Coyle, A. Gibb, y G. Haskins (Eds.), The entrepreneurial university: from concept to action (pp 10-16.). National Centre for Entrepreneurship in Education (NCEE). Retrieved from: https://ncee.org.uk/wp-content/uploads/2018/01/From-Concept-To-Action.pdf

[20] Guerrero, M., \& Urbano, D. (2012). The development of an entrepreneurial university. Journal of Technology Transfer, 37(1), 43-74. http://dx.doi.org/10.1007/s10961-010-9171-x

[21] Hernández, R., Fernández-Collado, C. \& Baptista, P. (2010). Metodología de la investigación. (4a ed). México: McGraw Hill.

[22] Hitt, M A., Ireland, R. D., Sirmon, D. G., \& Trahms, Ch. A. (2011). Entrepreneurship: Creating Value for Individuals, Organizations, and Society. Academy of Management Journal, May, 57-75. Retrieved from: https:// www.researchgate.net/publication/237081689_Creating_Value_for_Individuals_Organizations_and_Society

[23] Kairisto M. L. (2013). Aiming at Innovation Expertise. In Anttoni Letho y Tary Penttilä (eds.), Pedagogical Views on Innovation Competences and Entrepreneurship. Innovation pedagogy and other approaches (pp. 7-10). Turku: Juppi-Turun ammattikorkeakoulu. 
[24] Kelley, T. \& Littman, J. (2005). The Ten Faces of Innovation: IDEO's Strategies for Beating the Devil's Advocate and Driving Creativity Throughout Your Organization. USA: Crown Business.

[25] Liñán, F., Fernández-Serrano, J., \& Romero E. I. (2013). Emprendimiento por necesidad y por oportunidad: El efecto mediador de la cultura. Revista de Economía Mundial, 33, 21-47. R

[26] Madrigal, B. E. (2017). Habilidades Directivas. (3rd ed.). México: McGraw-Hill.

[27] Madrigal, B. E. \& Contreras, R. (2008). Paradigmas emergentes en ciencias administrativas. Paper presented at the meeting of ACACIA, Universidad de Guadalajara. Retrieved from: $\underline{\text { http://www.acacia.org.mx/revista/Paradigmas }}$ Libro.pdf

[28] Madrigal, B. E. \& Santamaria, C. (2013). Factores formales e informales del emprendruismo, capítulo del libro, Cuatro ejes para fomentar la cultura emprendedora. Retrieved from: https://www.researchgate.net/ publication/281870596

[29] Miranda, G., Molina, R., \& López, A. (2014). Social entrepreneurship in universities. The case of collaboration networks between MSMEs (Micro, small and medium enterprises) and the common land of the Ojo de agua de Ballesteros water park in Salvatierra, Guanajuato, Mexico. International Journal of Humanities and Social Science, 4(5), 21-30. Retrieved from: http://www.ijhssnet.com/journals/Vol 4 No 5 1 March 2014/4.pdf

[30] Nuñez, M. A., Wendlandt, T. R., Madrigal, B.E., Bejarano, B. Y., \& Banegas, R. A. (2018). The entrepreneurial university in Mexico: a pre-experimental study on entrepreneurial intention and skills. The Social Sciences, 13(1), 167-174. Retrieved from: http://medwelljournals.com/abstract/?doi=sscience.2018.167.174

[31] OECD. (2006). Manual de Oslo. Guía para la recogida e interpretación de datos sobre innovación. Comunidad Europea: OECD.

[32] Padilla Muñoz, R. (2017). La innovación en la dirección. In B. E. Madrigal Torres. Habilidades directivas. (3rd ed.). México: McGraw-Hill.

[33] Penttilä, T., Kairisto M., L., Putkonen, A., y Letho, A. (2013). Innovation Pedagogy - A Strategic Learning Approach for the Future. En Anttoni Letho y Tary Penttilä (eds.) Pedagogical Views on Innovation Competences and Entrepreneurship. Innovation pedagogy and other approaches (pp. 11-23). Turku: Juppi - Turun ammattikorkeakoulu.

[34] Putkone, A. (2013). RDI Integrating Theory and Practice. En Anttoni Letho y Tary Penttilä (eds.) Pedagogical Views on Innovation Competences and Entrepreneurship. Innovation pedagogy and other approaches (pp. 24-31). Turku: Juppi - Turun ammattikorkeakoulu.

[35] Schumpeter, J. (1934). The theory of economic development: An inquiry into profits, capital, credit, interest, and the business cycle. New Brunswick, NJ: Transaction Publishers.

[36] Schumpeter, J. (2003). Capitalism, socialism and democracy. (3rd ed.). USA: Taylor \& Francis.

[37] Schulte, P. (2004). The Entrepreneurial University: A Strategy for Institutional Development. Higher Education in Europe, 29(2), 187-191. https://doi.org/10.1080/0379772042000234811

[38] Watts, F., García-Carbonell, A., \& Andreu-Andrés, M. Á. (eds.). (2013). Innovation Competencies Development, INCODE Barometer and User Guide. Finland: Turku University of Applied Sciences.

[39] 50 Best U.S. Colleges for Aspiring Entrepreneurs (2014, june 27). Retrieved from: College Choice website: https:// www.collegechoice.net/best-colleges-for-entrepreneurs/ 
Annex 1. Measuring Instrument

\begin{tabular}{|c|c|c|c|c|c|c|c|c|c|c|c|c|}
\hline & Competency b & arometer fo & r inr & nov: & tion & & & & & & & \\
\hline & Assessment of achievem & ents in compe & etitic & ons & or inn & tion & & & & & & \\
\hline $\begin{array}{l}\text { Inst } \\
\text { abil }\end{array}$ & $\begin{array}{l}\text { uctions: Please do not leave blank spaces. Not all asse } \\
\text { ies; in many cases the appropriate response can be }\end{array}$ & $\begin{array}{l}\text { essments, tas } \\
0^{\prime \prime} .\end{array}$ & sks o & & uati & ead to & demo & & & & & \\
\hline Stu & ent Name: & & $\mathrm{Ve}$ & & & & 1 & 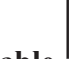 & & & F & 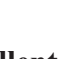 \\
\hline In $\mathbf{t}$ & e activities of the program / class, THE STUDENT: & & Lit & & Imp & ement & & & & & & \\
\hline & INDIVIDUAL & 0 & 1 & 2 & 3 & 4 & 5 & 6 & 7 & 8 & 9 & 10 \\
\hline 1 & Proposes ideas that are appropriate for the task & & & & & & & & & & & \\
\hline 2 & Proposes creative ideas & & & & & & & & & & & \\
\hline 3 & Proposes new ways to implement ideas & & & & & & & & & & & \\
\hline 4 & $\begin{array}{l}\text { Evaluates advantages and disadvantages of your } \\
\text { actions }\end{array}$ & & & & & & & & & & & \\
\hline 5 & $\begin{array}{l}\text { Identifies relationships between different } \\
\text { components of the task }\end{array}$ & & & & & & & & & & & \\
\hline 6 & Focuses the task from different points of view & & & & & & & & & & & \\
\hline 7 & Uses the available resources ingeniously & & & & & & & & & & & \\
\hline 8 & Anticipates how events will unfold & & & & & & & & & & & \\
\hline 9 & Shows enthusiasm & & & & & & & & & & & \\
\hline 10 & Pursues his/her goals persistently & & & & & & & & & & & \\
\hline 11 & Takes reasonable risks & & & & & & & & & & & \\
\hline 12 & Orients the task towards the objectives & & & & & & & & & & & \\
\hline & INTERPERSONAL & & & & & & & & & & & \\
\hline 13 & Transmits his/her ideas effectively & & & & & & & & & & & \\
\hline 14 & Listens to his/her teammates & & & & & & & & & & & \\
\hline 15 & $\begin{array}{l}\text { Establishes constructive group relationships through } \\
\text { dialogue }\end{array}$ & & & & & & & & & & & \\
\hline 16 & Actively collaborate & & & & & & & & & & & \\
\hline 17 & Contributes to the functioning of the groups & & & & & & & & & & & \\
\hline 18 & Takes the initiative & & & & & & & & & & & \\
\hline 19 & Encourages other to act & & & & & & & & & & & \\
\hline 20 & Conflicts with flexibility to reach agreements & & & & & & & & & & & \\
\hline & CREATION OF NETWORKS & & & & & & & & & & & \\
\hline 21 & Applies ethical values & & & & & & & & & & & \\
\hline 22 & $\begin{array}{l}\text { Takes into account the implications of the task for } \\
\text { society }\end{array}$ & & & & & & & & & & & \\
\hline 23 & Is able to work in multidisciplinary environments & & & & & & & & & & & \\
\hline 24 & Is able to work in multicultural environments & & & & & & & & & & & \\
\hline 25 & Use his/her contact networks to achieve goals & & & & & & & & & & & \\
\hline S & nts: Bachelor's degree, University, Gender, Age, Wor & & & & & & & & & & & \\
\hline & rsonales $+\mathrm{H}$ interpersonales $+\mathrm{CR}=\mathrm{HE}$ y $\mathrm{HI}$. & & & & & & & & & & & \\
\hline
\end{tabular}

